\begin{tabular}{l|l} 
Notaice & $\begin{array}{l}\text { e-ISSN: 2655-9404 p-ISSN: 2721-8376 } \\
\text { DOI: } 10.20473 / \text { ntr.v3i1.17536 }\end{array}$ \\
Vol. 3 No. 1, Februari 2020 &
\end{tabular}

Article history: Submitted 23 January 2020; Accepted 27 January 2020; Available online 1 February 2020.

\title{
Lahirnya Hak Tanggungan Menurut Peraturan Pemerintah Agraria Tentang Pelayanan Hak Tanggungan Terintegrasi Secara Elektronik
}

\author{
Nadia Imanda \\ Nadia.imanda96@gmail.com \\ Universitas Airlangga
}

\begin{abstract}
Provisions regarding mortgage rights refer to Law Number 4 of 1996 as well as other supplementary regulations. Over time, the Indonesian government in its application aspires to increase national development with a focus on the economy, in that case adequate funding is needed, so that institutions need strong guarantee rights, able to provide legal certainty for interested parties, supporting activities business, effective and efficient. Therefore, the implementation of the imposition of mortgage rights is simplified by the issuance of the Minister of Agrarian Regulation and Spatial Planning / Head of the National Land Agency Number 9 of 2019 concerning Electronic Integrated Mortgage Rights Services. With the issuance of Agrarian Regulation No. 9 of 2019 on Electronic Integrated Mortgage Rights Services, the Indonesian government aims to improve mortgage rights services that meet the principles of openness, timeliness, speed and convenience, making the concept of Mortgage Rights come into force uncertain. The Mortgage Rights attached to the principle of publicity, which is the prerequisite for the birth of the Mortgage Right, the recording in the land book is carried out to fulfill the publicity principle that makes the Mortgage Right open publicly, so that other parties not bound by the guarantee agreement know that there are property rights in of the land rights. Thus, the existence of Mortgage Online does not eliminate the obligation to meet publicity requirements to be known by the masses.

Keywords: Electronic Mortgage Rights; Land Agency; Principle of Publicity.
\end{abstract}

\begin{abstract}
Abstrak
Ketentuan-ketentuan mengenai Hak Tanggungan mengacu pada Undang-Undang Nomor 4 Tahun 1996 (UU HT) serta peraturan-peraturan pelengkap lainnya. Seiring berjalannya waktu, Pemerintah Indonesia dalam penerapannya bercita-cita untuk meningkatkan pembangunan nasional bertitik berat pada bidang ekonomi, dalam hal tersebut dibutuhkan penyediaan dana yang cukup, sehingga memerlukan lembaga hak jaminan kuat, mampu memberikan kepastian hukum bagi pihak-pihak yang berkepentingan, mendukung kegiatan bisnis, efektif dan efisien. Oleh karena itu, pelaksanaan pembebanan Hak Tanggungan dilakukan penyederhanaan proses dengan diterbitkannya Peraturan Menteri Agraria dan Tata Ruang/ Kepala Badan Pertanahan Nasional Nomor 9 Tahun 2019 tentang Pelayanan Hak Tanggungan Terintegrasi Secara Elektronik. Dengan terbitnya Permen Agraria dan Tata Ruang tersebut, Pemerintah Indonesia bertujuan untuk meningkatkan pelayanan Hak Tanggungan yang memenuhi asas keterbukaan, ketetapan waktu, kecepatan dan kemudahan membuat konsep terhadap momentum lahirnya Hak Tanggungan secara sah menjadi kabur. Pada Hak Tanggungan melekat asas publisitas, yang menjadi syarat lahirnya Hak Tanggungan tersebut, maka pencatatan dalam buku tanah dilakukan guna memenuhi asas publisitas yang menjadikan Hak Tanggungan itu terbuka dan umum, sehingga pihak lain yang tidak terikat pada perjanjian jaminan itu mengetahui bahwa adanya hak kebendaan di atas hak atas tanah tersebut. Sehingga, dengan adanya HT-el tidak menghapusnya adanya kewajiban untuk memenuhi syarat publisitas agar diketahui oleh masyarat. Kata Kunci: Hak Tanggungan Elektronik; Badan Pertanahan; Asas Publisitas.
\end{abstract}




\section{Pendahuluan}

Pemenuhan kebutuhan dan keinginan manusia kadang terhalang oleh sebab tertentu yang memposisikan manusia kekurangan suntikan dana demi mencapai hal yang ia cita-citakan. Untuk itulah, lembaga pendanaan hadir dalam masyarakat untuk membantu menyediakan dana bagi orang yang membutuhkan dengan diberikan suatu objek yang dapat dijaminkan kepada lembaga pendanaan tersebut supaya terjaga dari kerugian di kemudian hari jika debitor wanprestasi.

Bagi masyarakat, perorangan atau badan usaha yang berusaha meningkatkan kebutuhan konsumtif atau produktif sangat membutuhkan pendanaan dari bank sebagai salah satu sumber dana yang diantaranya dalam bentuk perkreditan, agar mampu mencukupi untuk mendukung peningkatan usahanya. Bank sebagai salah satu lembaga keuangan yang paling strategis perannya dalam masyarakat, bertujuan untuk menghimpun dana dari masyarakat baik dalam bentuk tabungan, deposito, giro atau lainnya dan menyalurkannya kembali dalam bentuk penyaluran kredit kepada masyarakat, baik kredit yang bersifat produktif atau konsumtif, oleh karenanya bank dikatakan sebagai agent of trust (agen kepercayaan pihak Pemerintah maupun pembangunan masyarakat) dan sebagai agent of development (agen pembangunan). ${ }^{1}$

Untuk menjaga kesehatan dari lembaga usaha perkreditan, khususnya bank, maka sudah semestinya usaha perkreditan ini diiringi pula dengan jaminan, hal ini bertujuan agar memberi keamanan dalam pemberian kredit dan kepastian pelunasan kredit tersebut. Sudah sepantasnya pemberi dan penerima kredit serta pihak lain yang terkait di dalamnya mendapat perlindungan melalui Lembaga jaminan yang dapat memberikan kepastian hukum bagi semua pihak yang terlibat dalam usaha perkreditan. ${ }^{2}$

Pada prinsipnya pengucuran kredit oleh bank memang tidak selalu harus disertai syarat adanya agunan, sebab jaminan sudah dianggap ada dengan melihat

1 Yulianto, Tanggung Jawab Notaris Dalam Membuat Akta Jaminan Kredit Perbankan (Mitra Usaha Abadi 2004).[1].

2 ibid. 
peluang dan prospek usaha yang cerah dari calon debitor. ${ }^{3}$ Namun, penyaluran kredit oleh bank tanpa adanya agunan membuka pintu risiko yang besar kepada bank selaku kreditor. Risiko kerugian itu dapat terjadi apabila debitor wanprestasi/cedera janji. Lain halnya, bila bank memiliki agunan, yang umumnya merupakan jaminan kebendaan, sehingga apabila debitor wanprestasi maka bank selaku pemegang jaminan dapat mengajukan eksekusi terhadap jaminan tersebut, dilakukan pelelangan umum kemudian kreditor mendapat penggantian dari hasil penjualan jaminan kebendaan tersebut.

BW memberikan dua Lembaga jaminan yang dapat digunakan oleh masyarakat yaitu lembaga jaminan gadai dan hipotek. Masing-masing diatur dalam Buku II BW Pasal 1150-1161 dan Pasal 1162-1232. Dalam perkembangan hukum di Indonesia, lahir dua lembaga jaminan baru, yaitu Lembaga jaminan fidusia dan Hak Tanggungan. Fidusia diatur dalam Undang-Undang Nomor 42 Tahun 1999 tentang Jaminan Fidusia (UU Fidusia), sedangkan Hak Tanggungan diatur dala Undang-Undang Nomor 4 Tahun 1996 tentang Hak Tanggungan atas Tanah Beserta Benda-benda yang Berkaitan dengan Tanah (UU Hak Tanggungan).

Pasal 1 angka 1 UU Hak Tanggungan menyebutkan bahwa Hak tanggungan atas tanah beserta benda-benda yang berkaitan dengan tanah, yang selanjutnya disebut Hak Tanggungan, adalah hak jaminan yang diberikan pada hak atas tanah sebagaimana dimaksud dalam Undang-Undang Nomor 5 Tahun 1960 tentang Peraturan Dasar Pokok-Pokok Agraria, berikut atau tidak berikut benda-benda lain yang merupakan satu kesatuan dengan tanah itu, untuk pelunasan utang tertentu, yang memberikan kedudukan yang diutamakan kepada kreditor tertentu terhadap kreditor-kreditor lain.

Ketentuan-ketentuan mengenai Hak Tanggungan mengacu pada UndangUndang Nomor 4 Tahun 1996 (UU HT) serta peraturan-peraturan pelengkap lainnya. Seiring berjalannya waktu, Pemerintah Indonesia dalam penerapannya bercita-cita untuk meningkatkan pembangunan nasional bertitik berat pada

3 M. Khoidin, Hukum Jaminan (Hak-Hak Jaminan, Hak Tanggungan Dan Eksekusi Hak Tanggungan) (Laksbang Yustitia 2017).[4]. 
bidang ekonomi, dalam hal tersebut dibutuhkan penyediaan dana yang cukup, sehingga memerlukan lembaga hak jaminan kuat, mampu memberikan kepastian hukum bagi pihak-pihak yang berkepentingan, mendukung kegiatan bisnis, efektif dan efisien.

Oleh karena itu, pelaksanaan pembebanan Hak Tanggungan dilakukan penyederhanaan proses dengan diterbitkannya Peraturan Menteri Agraria dan Tata Ruang/ Kepala Badan Pertanahan Nasional Nomor 9 Tahun 2019 tentang Pelayanan Hak Tanggungan Terintegrasi Secara Elektronik.

Menurut UU HT Pasal 10 ayat (2) "Pemberian Hak Tanggungan dilakukan dengan pembuatan Akta Pemberian Hak Tanggungan oleh PPAT sesuai dengan peraturan perundang-undangan yang berlaku," . PPAT menjalankan wewenang dan tugasnya untuk membuat APHT sebagaimana ketentuan pada Pasal 11 UU HT yang memuat syarat wajib APHT dan perihal janji-janji yang dapat dicantumkan dalam APHT tersebut. Setelah dibuat APHT oleh PPAT, Hak Tanggungan wajib didaftarkan pada Kantor Pertanahan sesuai dengan amanat Pasal 13 ayat (1) UU HT.

Pendaftaran Hak Tanggungan dilakukan oleh Kantor Pertanahan dengan membuatkan buku tanah Hak Tanggungan dan mencatatnya dalam buku tanah hak atas tanah yang menjadi objek Hak Tanggungan serta menyalin catatan tersebut pada sertifikat hak atas tanah yang bersangkutan.

Dengan terbitnya Permen Agraria Nomor 9 Tahun 2019, Pemerintah Indonesia bertujuan untuk meningkatkan pelayanan Hak Tanggungan yang memenuhi asas keterbukaan, ketetapan waktu, kecepatan, kemudahan, efektifitas dan efisiensi. Terbitnya Permen yang bersangkutan, berkonsekuensi kepada perubahan tata cara pemberian Hak Tanggungan yang semula dilakukan secara manual menjadi berbasis pada sistem elektronik yang terintegrasi.

Pelaksanaan Sistem HT-el ini diselenggarakn oleh Kantor Pertanahan secara bertahap menyesuaikan dengan kesiapan data pendukung. ${ }^{4}$ Terdapat empat jenis

\footnotetext{
4 Pasal 4 ayat (1) dan (2) Permen Agraria dan Tata Ruang/Badan Pertanahan Nasional Nomor 9 Tahun 2019
} 
layanan Hak Tanggungan yang dapat diajukan melalui Sistem HT-el, meliputi pendaftaran Hak Tanggungan, peralihan Hak Tanggungan, perubahan nama kreditor dan penghapusan Hak Tanggungan. ${ }^{5}$

Dalam tulisan ini akan dibahas terkait momentum lahirnya Hak Tanggungan menurut Permen Agraria Nomor 9 Tahun 2019 sebab dengan beralihnya tata cara pendaftaran Hak Tanggungan, kapan lahirnya Hak Tanggungan tersebut menjadi kabur dan tidak disebutkan dalam Permen Agraria Nomor 9 Tahun 2019 tersebut, padahal Permen tersebut menjadi acuan bagi Kreditor, Debitor, PPAT dan Kantor Pertanahan dalam menyelenggarakan pelayanan terkait Hak Tanggungan.

Berdasarkan uraian di atas maka dalam tulisan ini dirumuskan permasalahan terkait kapanlahirnya Hak Tanggungan yang didaftarkan melaluiSistem Pelayanan Hak Tanggungan Secara Elektronik (Sistem HT-el) dan perbandingannya dengan Undang-Undang Hak Tanggungan.

\section{Hak Tanggungan dalam Undang-Undang Nomor 4 Tahun 1996}

Hak Tanggungan diatur dalam Undang-Undang Nomor 4 Tahun 1996 yang diterbitkan sebagai pelaksana Pasal 51 dan 57 Undang-Undang Pokok Agraria (UUPA) dimaksudkan untuk mengakhiri dualisme dalam peraturan hak jaminan atas tanah yang sebeumnya menggunakan Lembaga jaminan hipotek dan credietverband. Melalui UUHT hak jaminan atas tanah dikonversi dan diunifikasi menjadi Hak Tanggungan. ${ }^{6}$

Dalam UUHT disebutkan dengan jelas kapan suatu hak atas tanah dibebani hak tanggungan. Hal tersebut dituangkan dalam Pasal 13 dan Pasal 14 UUHT, yang secara sistematis diuraikan sebagai berikut: ${ }^{7}$

1) Pendaftaran dilakukan di Kantor Pertanahan.

2) Pejabat Pembuat Akta Tanah (PPAT) dalam waktu 7 hari setelah ditandatanganinya pemberian Hak Tanggungan wajib mengirimkan Akta

5 Pasal 6 Permen Agraria dan Tata Ruang/Badan Pertanahan Nasional Nomor 9 Tahun 2019.

6 M. Khoidin (n 3).Op Cit. [52].

7 SH Bernadetha Aurelia Oktavira, 'Mekanisme Pendaftaran Hak Tanggungan Secara Elektronik' (HukumOnline.com, 2019) < https://www.hukumonline.com/klinik/detail/ulasan/lt5d78bcd61c63c/mekanisme-pendaftaran-hak-tanggungan-secara-elektronik/>. 
Pemberian Hak Tanggungan (APHT) dan warkah lainnya kepada Kantor Pertanahan beserta membawa berkas berupa:

a. Surat Pengantar dari PPAT yang dibuat rangkap dua dan memuat daftar jenis surat-surat yang disampaikan;

b. Surat permohonan pendaftaran Hak Tanggungan dari penerima Hak Tanggungan;

c. Fotocopy surat identitas pemberi dan pemegang Hak Tanggungan;

d. Sertifikasi asli hak atas tanah atau hak milik atas satuan rumah susun yang menjadi objek Hak Tanggungan;

e. Lembar kedua akta pemberian Hak Tanggungan;

f. Salinan akta pemberian Hak Tanggungan yang sudah diparaf oleh PPAT yang bersangkutan untuk disahkan sebagai salinan oleh Kepala Kantor Pertanahan untuk pembuatan Sertipikat Hak Tanggungan; dan

g. Bukti pelunasan biaya pendaftaran Hak Tanggungan.

3) Kantor Pertanahan membuatkan buku tanah Hak Tanggungan dan mencatatnya dalam buku tnah hak atas tanah yang menjadi objek Hak Tanggungan secara menyalin catatan tersebut pada sertipikat hak atas tanah yang bersangkutan.

4) Tanggal buku tanah Hak Tanggungan adalah tanggal hari ketujuh setelah penerimaan secara lengkap surat-surat yang diperlukan untuk pendaftaran. Jika hari ketujuh itu jatuh pada hari libur, buku tanah yang bersangkutan diberi tanggal hari kerja berikutnya.

5) Hak Tanggungan lahir pada hari tanggal buku tanah Hak Tanggungan dibuatkan.

6) Kantor Pertanahan menerbitkan Sertipikat Hak Tanggungan yang memuat irah-irah "Demi Keadilan Berdasarkan Ketuhanan Yang Maha Esa”, sehingga sertipikat tersebut memiliki kekuatan eksekutorial yang sama dnegan putusan pengadilan dan kemudian diserahkan kepada pemegang Hak Tanggungan.

Setelah terbit Permen Agraria Nomor 9 Tahun 2019, mekanisme pendaftaran

Hak Tanggungan mengalami perkembangan kearah teknologi dengan berbasis elektronik, maka ketentuan pendaftaran Hak Tanggungan menjadi sebagai berikut: ${ }^{8}$

1) Pengguna layanan Sistem HT-el terdiri dari perseorangan/badan hukum selaku kreditur dan Aparatur Sipil Negara Kementerian yang bertugas melayani Hak Tanggungan;

2) Terhadap perseorangan/badan hukum sebagaimana dimaksud sebelumnya harus menjadi pengguna terdaftar pada Sistem HT-el, dengan memenuhi 
persyaratan:
a. Mempunyai domisili elektronik;
b. Surat Keterangan Terdaftar di Otoritas Jasa Keuangan;
c. Pernyataan pemenuhan persyaratan dan kriteria serta persetujuan ketentuan sebagai Pengguna Terdaftar; dan
d. Syarat lainnya yang ditentukan oleh Kementerian.

3) Kementerian melakukan verifikasi atas pendaftaran dan berhak menolak pendaftaran dimaksud.

Setelah menjadi pengguna terdaftar, maka pengguna terdaftar melakukan mekanisme pendaftaran Hak Tanggungan sebagai berikut:

1) Pengguna terdaftar mengajukan permohonan layanan Hak Tanggungan secara elektronik melalui Sistem HT-el;

2) Selain berkas persyaratan permohonan pendaftaran dalam bentuk dokumen elektronik, pemohon juga membuat surat pernyataan mengenai pertanggungjawaban keabsahan dan kebenaran data dokumen elektronik yang diajukan. Khusus persyaratan berupa sertifikat hak atas tanah atau Hak Milik atas Satuan Rumah Susun harus atas nama debitur.

3) Permohonan layanan yang diterima oleh Sistem HT-el akan mendapatkan tanda bukti pendaftaran permohonan yang diterbitkan oleh sistem, dengan paling sedikit memuat nomor berkas pendaftaran permohonan, tanggal pendaftaran permohonan, nama pemohon, dan kode pembayaran biaya layanan.

4) Layanan Hak Tanggungan ini dikenakan biaya sesuai dengan ketentuan peraturan perundang-undangan mengenai Penerimaan Negara Bukan Pajak yang berlaku pada Kementerian. Setelah mendapatkan bukti pendaftaran permohonan, pemohon melakukan pembayaran biaya melalui bank persepsi paling lambat tiga hari setelah tanggal pendaftaran permohonan.

5) Setelah data permohonan dan biaya pendaftaran permohonan terkonfirmasi oleh sistem elektronik, Sistem HT-el akan memproses pencatatan Hak Tanggungan pada buku tanah. Pencatatan pada buku tanah dilakukan oleh Kepala Kantor Pertanahan. Sementara kreditur dapat melakukan pencatatan Hak Tanggungan pada Sertipikat Hak atas Tanah atau Hak Milik Satuan Rumah Susun dengan mencetak catatan yang diterbitkan oleh Sistem HT-el dan melekatkannya pada Sertipikat Hak atas Tanah atay Hak Milik Satuan Rumah Susun.

6) Setelah seluruh tahapan selesai, hasil layanan Hak Tanggungan yang dikeluarkan berupa Sertipikat Hak Tanggungan dan Catatan Hak Tanggungan pada buku tanah dan Sertipikat Hak atas Tanah atau Hak Milik atas Satuan Rumah Susun. Dokumen ini diterbitkan pada hari ketujuh setelah pengajuan permohonan terkonfirmasi. Dalam rangka menjaga keutuhan dan keautentikan dokumen elektronik, Sertipikat Hak Tanggungan yang diterbitkan oleh Sistem HT-el diberikan tanda tangan elektronik. 
7) Sebelum hasil layanan Hak Tanggungan diterbitkan, Kepala Kantor Pertanahan atau Pejabat yang ditunjuk harus memerika konsep sertipikat HT-el dan dokumen kelengkapan permohonan. Kepala Kantor Pertanahan atau Pejabat yang ditunjuk bertanggung jawab secara administraf atas hasil layanan Hak Tanggungan. Dalam hal Kepala Kantor Pertanahan atau Pejabat yang ditunjuk tidak melakukan pemeriksaan, Kepala Kantor Pertanahan atau Pejabat yang ditunjuk dianggap memberikan persetujuan.

8) Sementara kebenaran materiil dokumen yang menjadi dasar hasil layanan Sistem HT-el bukan merupakan tanggung jawab Kantor Pertanahan.

Seperti yang dipaparkan di atas, bahwa dalam mekanisme pendaftaran Sistem HT-el, Hak Tanggungan tetap harus dicatatkan dalam buku tanah, namun yang menjadi pembeda antara UUHT dengan Permen Agraria dan Tata Ruang/ Badan Pertanahan Nasional Nomor 9 Tahun 2019 adalah kreditur dapat melakukan pencatatan Hak Tanggungan pada Sertipikat Hak Tanah atau Hak Milik Satuan Rumah Susun itu sendiri dengan mencetak catatan yang diterbitkan oleh Sistem HT-el dan melekatkannya pada Sertipikat Hak atas Tanah atau Hak Milik Satuan Rumah Susun.

Fakta hukum tersebut memberikan kekaburan terhadap momentum lahirnya Hak Tanggungan, apakah Hak Tanggungan lahir saat kreditur mencetak catatan yang diterbitkan oleh Sistem HT-el kemudian melekatkannya pada Sertipikat Hak atas Tanah atau Hak Milik Satuan Rumah Susun atau ketika Hak Tanggungan tersebut dicatatkan dalam buku tanah oleh Kepala Kantor Pertanahan, sebab adanya kemungkinan bahwa dua hal tersebut terjadi tidak pada waktu yang sama. Perbedaan perspektif terjadinya Hak Tanggungan akan berkonsekuensi pada eksistensi Hak Tanggungan ketika terjadi sengketa.

\section{Lahirnya Hak Tanggungan Menurut Permen Agraria Nomor 9 Tahun 2019}

Oleh karena itu, untuk menentukan momentum lahirnya Hak Tanggungan yang didaftarkan melalui Sistem HT-el maka kita dapat menulik kepada asas-asas Hak Tanggungan. Hak Tanggungan memiliki beberapa ciri-ciri pokok, yaitu: ${ }^{9}$

a) Memberikan kedudukan diutamakan (preferensi) kepada kreditur- 
krediturnya;

b) Selalu mengikuti objeknya dalam tangan siapapun berada;

c) Memenuhi asas spesialitas dan publisitas; dan

d) Mudah serta pasti pelaksanaan eksekusinya.

Kemudian secara lebih terperinci Sutan Remy Sjahdeini menyebutkan asasasas hak tanggungan yang tersebar dalam berbagai pasal Undang-Undang Hak Tanggungan, yaitu: ${ }^{10}$

1) Hak Tanggungan memberikan kedudukan yang diutamakan bagi kreditur pemegang hak tanggungan;

2) Hak Tanggungan tidak dapat dibagi-bagi;

3) Hak Tanggungan hanya dapat dibebankan pada hak atas tanah yang telah ada;

4) Hak Tanggungan dapat dibebankan selain atas tanahnya juga berikut dengan benda-benda yang berkaitan dengan tanah tersebut;

5) Hak Tanggungan dapat dibebankan juga atas benda-benda yang berkaitan dengan tanah yang baru aka nada di kemudian hari;

6) Hak tanggungan bersifat accesoir;

7) Hak Tanggungan dapat dijadikan jaminan untuk hutang yang baru akan ada.

8) Hak Tanggungan dapat menjamin lebih dari satu hutang;

9) Hak Tanggungan mengikuti objeknya dalam tangan siapapun objek hak tanggungan itu berada;

10) Di atas Hak Tanggungan tidak dapat dilakukan sita oleh pengadilan;

11) Hak Tanggungan hanya dapat dibebankan atas tanah tertentu (asas spesialitas);

12) Hak Tanggungan wajib didaftarkan (asas publisitas);

13) Hak Tanggungan dapat diberikan dengan disertai janji-janji tertentu;

14) Objek Hak Tanggungan tidak boleh diperjanjikan untuk dimiliki sendiri oleh pemegang hak tanggungan bila debitur cidera janji;

15) Pelaksanaan eksekusi hak tanggungan mudah dan pasti.

Pada dasarnya sistem elektronik adalah serangkaian perangkat dan prosedur elektronik yang berfungsi mempersiapkan, mengumpulkan, mengolah, menganalisis, menyimpan, menampilkan, mengumumkan, mengirimkan, dan/ atau menyebarkan Informasi Elektronik. Sehingga penyelenggaraan sistem elektronik dapat dilakukan oleh penyelenggara negara, Orang, Badan Usaha, dan/atau masyarakat. ${ }^{11}$

\footnotetext{
${ }^{10}$ M. Khoidin (n 3).Op Cit.[81-82].

11 Begiyama Fahmi Zaki, 'Kepastian Hukum Dalam Pelelangan Objek Hak Tanggungan Secara Online’ (2016) 10 Fiat Justisia.[379].
} 
Dalam mewujudkan sistem yang efektif dan efisien maka dibutuhkan adanya kerjasama yang komprehensif dari pihak-pihak yang berkepentingan. Terdapat tiga pilar unsur terlaksanya Hak Tanggungan Elektronik, antara lain:

1. Tiga unsur tersebut yaitu Bank, PPAT, Kantor Pertanahan, merupakan unsur SDM yang menentukan dapat terlaksananya HT-E dengan mudah dan sesuai dengan yang dihadapkan oleh Pemerintah dan masyarakat. Tiga pilar unsur tersebut di atas yaitu Bank, PPAT, Kantor Pertanahan mempunyai fungsi membantu tugas Pemerintah;

2. Dalam memberikan layanan HT-el perlu ditunjang dengan peralatan yang canggih yang bisa menjadi sarana penyimpanan data dan pengiriman data sehingga bisa saling terintergrasi antara Kantor Pertanahan daerah dengan Kantor Wilayah Badan Pertanahan Nasional Provinsi. Layanan HTel merupakan bentuk pemberian pelayanan dari Kementerian ATR/BPN dalam mempermudah layanan kepada masyarakat dengan memanfaatkan perkembangan teknologi informasi;

3. Peraturan Menteri Agraria dan Tata Ruang/Kepala Badan Pertanahan Nasional Nomor 9 Tahu 2019 tentang Pelayanan Hak Tanggungan Terintegrasi Secara Elektronik adalah serangkaian proses pelayanan Hak Tanggungan dalam rangka pemeliharaan data pendaftaran tanah yang diselenggarakan melalui sistem elektronik yang terintegrasi. ${ }^{12}$

Sapat dilihat adanya kemajuan pemikiran Pemerintah untuk dapat menanggulangi kebutuhan masyarakat serta mengikuti perkembangan teknologi yang semakin canggih. Namun diperlukan adanya konsistensi terhadap penerapan HT-el yang dapat dimulai dengan melakukannya secara menyeluruh dan merata di seluruh Badan Pertanahan di Indonesia.

\section{Asas Publisitas dalam Konsep Hak Tanggungan}

Dari penjabaran asas-asas Hak Tanggungan di atas, dapat dilihat bahwa pada

\footnotetext{
${ }^{12}$ Nurul Nadira, 'Pendaftaran Hak Tanggungan Elektronik Yang Akan Mulai Dilaksanakan Di Badan Pertanahan’ (2019) 17 Fairness and Justice: Jurnal Ilmiah Ilmu Hukum.[163-164].
} 
Hak Tanggungan melekat asas publisitas. Asas publisitas (openbaarheid) berlaku untuk benda tidak bergerak yang diberikan hak kebendaan. Asas publisitas yakni “pengumuman" kepada masyarakat mengenai status pemilikan. Pengumuman hak atas benda tetap (tanah) terjadi melalui pendaftaran dalam buku tanah, sedangkan pengumuman benda bergerak melalui penguasaan nyata benda itu.

Asas publisitas membawa pengaruh penting terhadap perjanjian jaminan kebendaan yang dibuat oleh debitor dan kreditor. Pemenuhan asas publisitas mengakibatkan bahwa perjanjian jaminan kebendaan tersebut tidak sekedar berlaku dan mengikat para pihak saja, tetapi juga akan mengikat pihak ketiga sehingga ada suatu kewajiban yang terpikul di pundaknya yakni keharusan menghormati hak kebendaan yang dimaksud. Asas publisitas ini menjadi penting agar supaya perjanjian jaminan kebendaan yang dibuat oleh kreditor dan debitor, juga mempunyai kekuatan mengikat terhadap pihak ketiga kendati bukan merupakan pihak seperjanjian. ${ }^{13}$

Asas publisitas dapat diartikan bahwa Hak Tanggungan dapat mengikat pihak ketiga dan memberikan kepastian hukum kepada pihak-pihak yang berkepentingan, jika telah didaftarkan di kantor pertanahan sehingga terbuka dan diketahui oleh umum. ${ }^{14}$

Jaminan kebendaan seperti Hak Tanggungan merupakan hak kebendaan yang diberikan atas dasar jura in re alinea, dan karenanya wajib memenuhi asas pencatatan dan publisitas agar dapat melahirkan hak atas kebendaan yang dijaminkan tersebut. Lahirnya hak kebendaan pada hak kebendaan yang bersifat memberikan jaminan, yaitu digantungkan pada penerapan dari asas publisitas, dengan mendaftarkan ke Kantor Pertanahan maka lahirlah hak kebendaan. ${ }^{15}$

Oleh sebab itu, Pasal 13 ayat (1) Undang-Undang Hak Tanggungan menyatakan bahwa "Pemberian Hak Tanggungan wajib didaftarkan pada Kantor Pertanahan." Dan dalam bagian penjelasan pasal ini dikatakan bahwa salah satu

${ }_{13}$ Isnaeni Moch, Pengantar Hukum Jaminan Kebendaan (PT Revka Petra Media 2016).[146-147].

${ }^{14}$ Imron Rosyadi, Jaminan Kebendaan Berdasarkan Akad Syariah (Kencana 2017).[95]. [235-236].

15 Juliana Evawati, 'Asas Publisitas Pada Hak Jaminan Atas Resi Gudang' (2014) 29 Yuridika. 
asas Hak Tanggungan adalah asas publisitas. Oleh karena itu, didaftarkannya pemberian Hak Tanggungan merupakan syarat mutlak untuk lahirnya hak tanggungan tersebut dan mengikatnya Hak Tanggungan terhadap pihak ketiga. ${ }^{16}$

Dengan adanya Sistem HT-el yang memungkinkan kreditur untuk mencetak sendiri yang diterbitkan oleh Sistem HT-el kemudian melekatkannya pada Sertipikat Hak atas Tanah atau Hak Milik Satuan Rumah Susun, hal tersebut tidak semerta-merta menjadikan Hak Tanggungan lahir, apabila belum dilakukan pencatatan pada buku tanah oleh Kepala Kantor Pertanahan, sebab pencatatan dalam buku tanah tersebut dilakukan guna memenuhi asas publisitas yang menjadikan Hak Tanggungan itu terbuka dan umum, sehingga pihak lain yang tidak terikat pada perjanjian jaminan itu mengetahui bahwa adanya hak kebendaan di atas hak atas tanah tersebut yaitu Hak Tanggungan.

\section{Kesimpulan}

Dengan munculnya Sistem HT-el yang bertujuan untuk mempermudah pendaftaran Hak Tanggungan, dibuatlah klausa bahwa kreditur dapat mencetak sendiri catatan yang diterbitkan oleh Sistem HT-el kemudian melekatkannya pada Sertipikat Hak atas Tanah atau Hak Milik Satuan Rumah Susun, hal ini memberikan ketidakjelasan atas kapan lahirnya Hak Tanggungan tersebut. Namun, kembali pada asas hukum jaminan yang melekat pada Hak Tanggungan, yakni asas publisitas bahwa Hak Tanggungan wajib memenuhi asas publisitas agar dapat melahirkan hak atas kebendaan yang dijaminkan tersebut. Sehingga, Hak Tanggungan harus bersifat terbuka dan umum agar pihak lain selain kreditur dan debitur dapat mengetahui bahwa di atas hak atas tanah tersebut telah dibebani hak lain yaitu hak jaminan kebendaan dalam bentuk Hak Tanggungan yang dapat dilihat dari buku tanah di Kantor Pertanahan. Aspek itulah yang menjadi inti dari proses pendaftaran Hak Tanggungan, bahwa pembebanan Hak Tanggungan juga perlu diketahui oleh masyarakat agar tidak terjadi sengketa di kemudian hari.

16 Abdul R Saliman, Hukum Bisnis Untuk Perusahaan (5th edn, Kencana 2005).[23]. 


\section{Daftar Bacaan}

\section{Buku}

M. Khoidin, Hukum Jaminan (Hak-Hak Jaminan, Hak Tanggungan Dan Eksekusi Hak Tanggungan) (Laksbang Yustitia 2017).

Maria SW Soemardjono, Hak Tanggungan Dan Fidusia (Citra Aditya Bakti 1996).

Moch I, Pengantar Hukum Jaminan Kebendaan (PT Revka Petra Media 2016).

Rosyadi I, Jaminan Kebendaan Berdasarkan Akad Syariah (Kencana 2017).

Saliman AR, Hukum Bisnis Untuk Perusahaan (5th edn, Kencana 2005).

Yulianto, Tanggung Jawab Notaris Dalam Membuat Akta Jaminan Kredit Perbankan (Mitra Usaha Abadi 2004).

\section{Jurnal}

Juliana Evawati, 'Asas Publisitas Pada Hak Jaminan Atas Resi Gudang' (2014) 29 Yuridika.

Nurul Nadira, 'Pendaftaran Hak Tanggungan Elektronik Yang Akan Mulai Dilaksanakan Di Badan Pertanahan' (2019) 17 Fairness and Justice: Jurnal Ilmiah Ilmu Hukum.

Zaki BF, 'Kepastian Hukum Dalam Pelelangan Objek Hak Tanggungan Secara Online' (2016) 10 Fiat Justisia.

\section{Laman}

Bernadetha Aurelia Oktavira SH, 'Mekanisme Pendaftaran Hak Tanggungan Secara Elektronik' (HukumOnline.com, 2019). <https:/ / www.hukumonline. com/klinik/detail/ulasan/lt5d78bcd61c63c/mekanisme-pendaftaran-haktanggungan-secara-elektronik/>.

How to cite: Nadia Imanda, 'Lahirnya Hak Tanggungan Menurut Peraturan Pemerintah Agraria Tentang Pelayanan Hak Tanggungan Terintegrasi Secara Elektronik' (2020) Vol. 3 No. 1 Notaire. 
164 Nadia Imanda: Lahirnya Hak Tanggungan...

--Halaman ini sengaja dikosongkan-- 